\title{
Transglutaminase Polymerization of Peanut Proteins
}

Clare, D.A. ${ }^{1}$, G. Gharst G. ${ }^{1}$ and T.H. Sanders ${ }^{2}$. Department of Food Science ${ }^{1,2}$, USDA/ARS ${ }^{2}$ Schaub Hall, North Carolina State University, Raleigh, N.C. 27695-7624, USA.

email: debra_clare@ncsu.edu

INTRODUCTION: Transglutaminase (TGase) [protein-glutamine:amine $\gamma$-glutamyltransferase, EC 2.3.2.13] promotes protein cross-linking reactions through an acyl transferase mechanism (1) involving protein-bound glutaminyl residues and primary amines, including the $\varepsilon$-amino group of lysine residues in soy, myosin, gluten, oat globulin, casein and whey $(2,3,4)$. Herein, we present a first report of microbial TGase catalysis of protein fractions prepared from peanut, Arachis hypogaea L., and the effects of polymerization on experimental parameters listed below.

OBJECTIVES: Characterize the effects of TGase covalent cross-linking reactions on $(i)$ SDS-PAGE banding patterns, $(i i)$ the degree of peanut protein (PP) polymerization, and (iii) $\mathrm{IgE}$ reactivity with TGase modified $\mathrm{PP}$ and glycoprotein conjugates.

METHODS: SDS-PAGE electrophoresis, $O$-Phthaldialdehye (OPA) analyses, and enzyme linked immunosorbent (ELISA) assays were accomplished according to standard procedures.

RESULTS: (1) TGase polymerization of lightly roasted peanut flour dispersions, containing $12 \%$ fat (LR-12), resulted in a wide distribution of higher molecular weight species (Fig.1A) while cross-linking of purified Ara h1 resulted in distinct dimer formation (Fig. 1B).

\section{Figure 1: $\quad$ TGase Polymerization of Peanut Protein Dispersions}

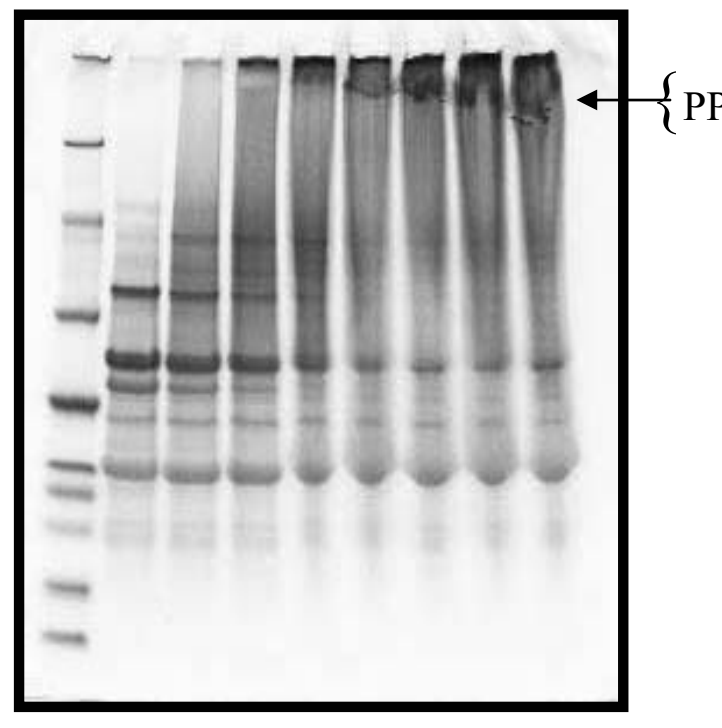

0 h $0.5 \mathrm{~h} 1 \mathrm{~h} 2 \mathrm{~h} 4 \mathrm{~h} 6 \mathrm{~h} 9 \mathrm{~h} 24 \mathrm{~h}$

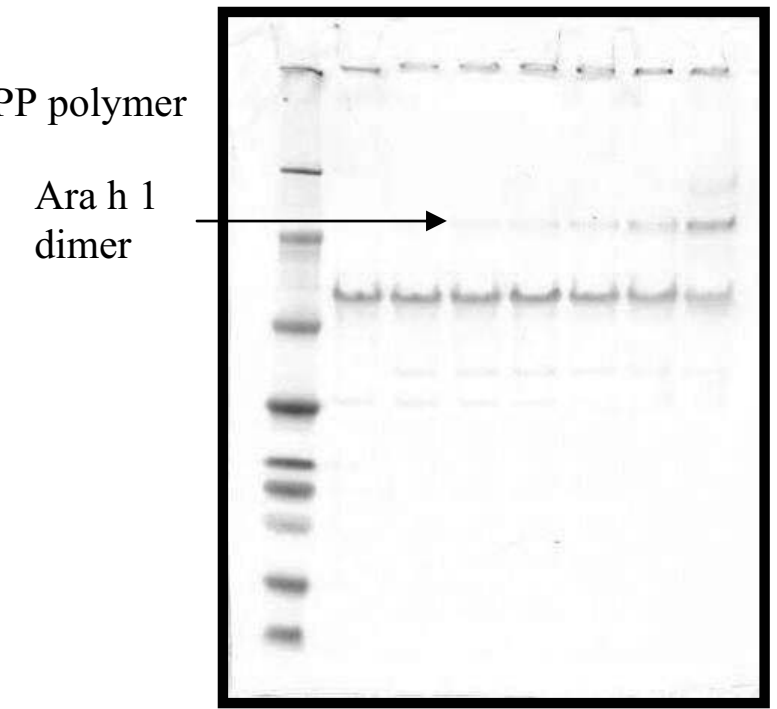

$0 \mathrm{~h} 0.5 \mathrm{~h} 1 \mathrm{~h} 2 \mathrm{~h} 3 \mathrm{~h} 5 \mathrm{~h} 20 \mathrm{~h}$

(B) Purified Ara h1 (+) TGase 
(2): OPA assays revealed $\sim 30 \%$ coupling after incubation of LR-12 PP dispersions with TGase for $\sim 4$ h at $37^{\circ} \mathrm{C}$.

Table 1: Quantitative Analysis of TGase Cross-linking: (LR-12) (OPA assay)

\begin{tabular}{|l|l|l|}
\hline PP Sample & Incubation Time & $\mathrm{A}_{340 \mathrm{~nm}}$ \\
\hline LR-12 $(-)$ TGase & $0 \mathrm{~h}$ & $.84 \pm 0.04$ \\
\hline LR-12 (+) TGase & $2 \mathrm{~h}$ & $.68 \pm 0.05$ \\
\hline LR-12 (+) TGase & $4 \mathrm{~h}$ & $.58 \pm 0.03$ \\
\hline
\end{tabular}

(3) IgE responses, an indicator of potential allergic reactions, were measured for LR-12 $\mathrm{PP}$ and glycoPP-conjugates, created by TGase linkage of monosaccharide amino sugars with LR-12 protein substrates. These results showed slightly elevated IgE binding to all polymers as compared to LR-12 (control).

Figure 2: ELISA Results

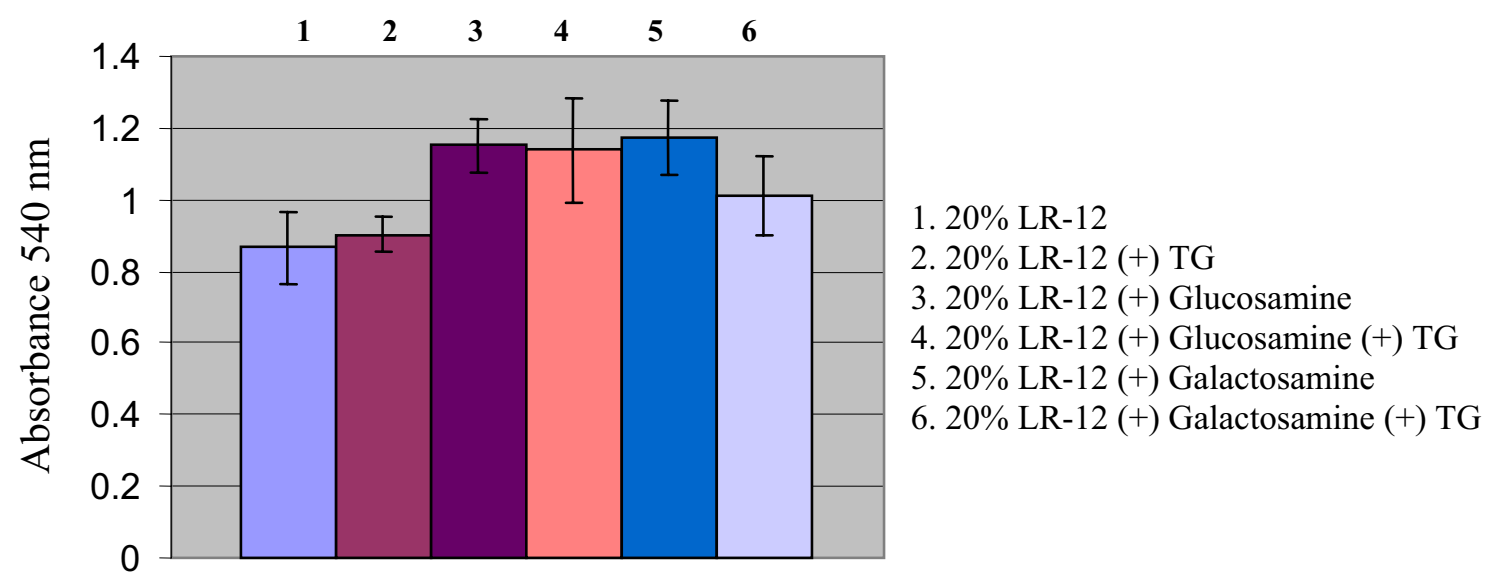

CONCLUSIONS: The polymerization of PP was catalyzed by microbial TGase, and lightly roasted PP samples were cross-linked $\sim 30 \%$. TGase modification did not diminish IgE binding responses.

\section{REFERENCES:}

1. Folk J.E. and Chung S.I. (1985) Transglutaminases. Methods Enzymol. 113: 358375.

2. Motoki, M. and Seguro, K. (1998) Transglutaminase and its use in food processing. Trends in Food Sci. and Technol. 9: 204-210.

3. Siu N.C., Ma C.Y., Mock W.Y. and Mine Y. (2002) Functional properties of oat globulin modified by calcium-independent microbial transglutaminase. J. Agric. Food Chem. 50: 2666-2672.

4. Nielsen PM (1995) Reactions and potential industrial applications of transglutaminase: review of literature and patents. Food Biotech. 3: 119-156.

Keywords: Peanut proteins, Transglutaminase, and Allergenicity 